\title{
O czytaniu i odczytaniu dziel literatury staropolskiej Czy językoznawca czyta inaczej?
}

Słow a klucze: analiza historycznojęzykowa, transkrypcja i transliteracja tekstu dawnego, oznaczanie barwy samogłosek, cechy grafii starodruku, cechy rękopiśmienne

Można przypuszczać, że - skoro każdy z odbiorców dzieła literackiego, w tym także językoznawca, przeczyta ten sam utwór - będzie on przez każdego z nich odebrany w taki sam sposób. O tym, czy tak się stanie, nie świadczy jednak wyłącznie kwestia obcowania z tym samym, utrwalonym w piśmie tekstem, ale również to, jak, czy, na ile zostanie on przez czytelnika zrozumiany, zinterpretowany. Powstałe w trakcie lektury wyobrażenie o tekście buduje w świadomości odbiorcy replikę oryginału - im większa świadomość językowa odbiorcy, tym bliższe owo wyobrażenie temu, co w tym tekście rzeczywiście się znalazło.

Problem zasygnalizowany w tytule jest rozległy i wielowarstwowy. Dotyczy tego, jakie mogą powstać różnice w odbiorze tego samego tekstu przez czytelników z różnymi kompetencjami, w tym wypadku: ze zróżnicowaną świadomością języka epoki, w której ów tekst powstał. W artykule poruszę zatem następującą kwestię: na ile wiedza z zakresu językoznawstwa historycznego może wpływać na odczytanie dzieła literatury staropolskiej, ale także - czy sama szczegółowa wiedza z tego zakresu będzie wystarczająca 
przy odbiorze i analizie tekstu dawnego, bez uciekania się do wiedzy pozajęzykowej. Na podstawie wybranych niewielkich fragmentów tekstów pochodzących z pierwszej fazy epoki średniopolskiej (w ujęciu historycznojęzykowym) unaocznię wieloaspektowość i złożoność tej problematyki.

Dla badań nad leksyką istotne znaczenie ma opis konkretnych leksemów, a u jego podstaw leży oczywiście ich należyte wyodrębnienie, dalej również ich odpowiednia charakterystyka formalna i semantyczna. Czytelnik mający do dyspozycji fragment z utworu Stanisława Gosławskiego jedynie w transkrypcji, bez noty objaśniającej:

(1) Wyschta, wybladta, schudta i żebra w niej zliczy. (GosłCast 27) ${ }^{1}$

nie będzie w stanie orzec z całą pewnością, do jakiej klasy leksemów należą wyróżnione wyrazy. W tym wypadku można mieć wątpliwości, czy w trójczłonowym ciągu szeregowym zapisano formy $3 \mathrm{sg}$ praet $f$ czasowników: wyschnqć, wybladnać, schudnqć, czy $N$ sg $f$ od part praet act: wyschty, wybladty, schudty (w odmianie prostej lub złożonej). Rozstrzygająca będzie dopiero znajomość zapisu oryginalnego, wraz z oznaczeniami barwy samogłosek w końcówkach gramatycznych:

(1.a) Wyfchtá/ wybládtá/ fchudtá/ y żebrá w niéy zliczy. (GosłCast 27)

W zabytku normą jest oznaczanie znakiem diakrytycznym $a$ jasnego, stąd z miejsca można odrzucić możliwość wystąpienia w badanym zdaniu imiesłowów odmiany złożonej, ponieważ w tej pozycji wystąpiłaby w końcówce samogłoska pochylona. Skoro w druku zapisano $a$ jasne, pozostają zatem jeszcze dwie ewentualności: czasownik lub imiesłów odmieniający się według paradygmatu rzeczownikowego. Tu z kolei za przyjęciem lub odrzuceniem ostatniej możliwości przemawiać mogą uwarunkowania syntaktyczne, które w tym wypadku nie dostarczą wystarczających argumentów. Najrozsądniej zatem nie orzekać definitywnie, z jaką klasą leksemów mamy tu do czynienia, choć bardziej prawdopodobne wydaje się czasownikowe odczytanie wskazanych form. Pewnych przesłanek dostarcza bowiem fakt, iż Castus

1 Wszystkie cytaty (wraz z uzupełnieniami, dopowiedzeniami i wyróżnieniami) o ile nie podano inaczej - w transkrypcji i transliteracji autorki. Skróty źródłowe za SPXVI (rozwiązane na końcu artykułu). 
Ioseph jest thumaczeniem łacińskiego dramatu Szymonowica, zatem - korzystając już z pozajęzykowych danych - można odnieść się do oryginału, w którym użyto właśnie form czasownikowych: Quam concidit, quam tabuit, quam marcuit! ${ }^{2}$. Jednakże również odwołanie do faktów pozajęzykowych każe, mimo wszystko, zachować ostrożność sądów, ponieważ tlumacz w wielu miejscach rezygnował ze ścisłego przekładu tekstu łacińskiego, tu np. dodał od siebie, a wbrew oryginałowi, drugą część analizowanego zdania.

Kolejny, bardzo ciekawy przykład dotyczy poprawnej rekonstrukcji formy podstawowej rzeczownika w utartych formułach zdaniowych, np.:

(2) Nie było nigdzyey rownia/ tákiemu cżtowieku. (RejZwierz 1)

(3) á fwoię [żonę] zábit [Herod Antypas] imieniem Máryánnęl ktora tákiey cudnośći byłál iż iey ná ten cżás fwiát rownia nie miał (BielKron 139v)

W tym wypadku również rozstrzygająca będzie kwestia barwy samogłoski w końcówce gramatycznej. Analiza językowa pozwoli na właściwe odtworzenie na tej podstawie formy mianownikowej, choć ta może budzić uzasadnione wątpliwości odbiorcy współczesnego, nieposiadającego wystarczających kompetencji historycznojęzykowych. Bezwyjątkowe występowanie w końcówce gramatycznej formy $G s^{3}$ samogłoski pochylonej każe od-

2 Stosunek tekstu przekładu do oryginału łacińskiego omówił Jerzy Axer (Górski, Kaufmanowa 1973: 32) w części wstępnej krytycznego wydania utworu w postaci reprodukcji fototypicznej oraz transkrypcji, wykazując liczne niedociągnięcia warsztatowe tłumacza. Dopiero owo szczegółowe zestawienie obu tekstów daje podstawy do podobnych wniosków oraz każe w związku z tym zachować daleko idącą ostrożność przy dokonywaniu uściśleń dotyczących kwestii językowych polskiego zabytku na podstawie odniesień do powstałego w 1587 r. łacińskiego oryginału. W wydaniu Romana Zawilińskiego (Zawiliński 1889) omawianego tłumaczenia zabrakło należytego porównania obu tekstów (choć wskazano tu również pewne nieścisłości w przekładzie), stąd jego pochlebny sąd o stylu i wierności tłumaczenia Gosławskiego, ugruntowany wcześniej w Dykcyjonarzu Juszyńskiego. Ocena taka nie przetrwała jednak próby czasu - por. pierwsze wzmianki o ,zmianie myśli Szymonowica” w polskim dramacie sformułowane przez Piotra Chmielowskiego (1898: 71) lub ocenę Wiktora Hahna: „Przekład to nadzwyczaj nieudolny, rozwlekły (oryginał [obejmujący 1756 wersów - ALK] rozrósł się w nim do 2056 wierszy), pełen rubaszności i trywialności” (Hahn 1906: 443). Zob. też Nadolski (1952: 11-12).

3 SPXVI notuje 33 formy G sg omawianego rzeczownika; wszystkie zapisy potwierdzają obecność samogłoski pochylonej w końcówce gramatycznej. 
tworzyć postać mianownikową jako rzeczownik w rodzaju nijakim: rownie, a nie - jak byśmy się dziś spodziewali - w rodzaju męskim rowień.

W powyżej opisanych wypadkach problemem jest jedynie kwestia rozstrzygnięcia, do jakiej klasy leksemów należą zapisane wyrazy. Niezależnie od poruszonych kwestii, zacytowane fragmenty utworów są w pełni zrozumiałe dla odbiorcy, bez względu na jego kompetencje językowe, więc owe dywagacje mogą wydać się mało istotne. Są jednak i takie sytuacje, kiedy znajomość średniopolskiego systemu fonetycznego oraz graficznego może mieć walor rozstrzygający, gdy kontekst nie pozwala na pewne odczytanie jakiegoś fragmentu, jak np. w wypadku form (pozornie) homonimicznych panie: dla $V$ sg pan oraz $N-V$ pl pani. Tu decydująca będzie barwa końcówki gramatycznej - $e$ jasne dla rzeczownika pan oraz e pochylone dla pani.

Przedstawiony problem ma jednak jeszcze szerszy wymiar. Dla przykła$\mathrm{du}$, przedstawione poniżej $\mathrm{w}$ transliteracji zdania zapisane $\mathrm{w}$ transkrypcji mogłyby nie dać możliwości już nie tylko adekwatnej charakterystyki gramatycznej wyróżnionych wyrazów, lecz wręcz zrozumienia przekazu:

(4) TY Jpifz/ á ia fám ná dworzel Ie cze od wieczornéy zorze/ Ciérpię nocné niepogody: Víátuy fye moiéy fzkody (KochPieś 24)

(5) Gdźie poźrzę/ wjzędy widzę Polfkiéy sily znáki/ Tu do czarnégo morzá iefcze świéże fzláki: Tu drógá znákomita przez śniéżné Bátchány: Tu pśié polá/ á fám brzég Prufki zwoiowány. (KochCz A3v)

(6) A tak żebych niezoftal przed brama, iako Bergamafzek, wolalem fám doma pocżekac (KochList nlb. 1)

W zdaniach tych w wyrazie sam pojawiło się $a$ jasne, w odróżnieniu od również licznych zapisów z a pochylonym, np.:

(7) Iuż názad niechodź/ Orpheu/nie vmiateś chowáć/ Ześ fye y fam wrócit/ możefz Bogu dźiękowáć. (KochTarn 77)

(8) Téż vftáwiono ieft: iż żaden Zupnik nie ma fam foli przedáwáć ná Skłádźie Krákowfkim/ áni żaden Jtugá Zupników (SarnStat 373)

We wszystkich tych zdaniach kontekst nie pozwoliłby na uchwycenie semantycznych różnic między poszczególnymi użyciami leksemu sam, uwidoczniło się natomiast w sposób charakterystyczny rozróżnianie barwy sa- 
mogłosek jako żywa cecha dystynktywna. W zdaniach (7) i (8) mamy zatem do czynienia z zaimkiem odmieniającym się według paradygmatu przymiotnikowego w znaczeniu 'bez towarzystwa; samodzielnie', zapisanym z pochyloną samogłoską $a$, natomiast w zdaniach (4), (5) i (6) - z przysłownym sam 'tu', z samogłoską jasną.

Owa dychotomia daje jasne podstawy do orzekania o leksemach na podstawie cech językowych, abstrahując od niejednoznacznego kontekstu. Zaimek ze zdania (4) SPJK również odczytał jako przysłowny, choć w krytycznych edycjach Pieśni Kochanowskiego interpretacja nie zawsze jest tak ukierunkowana. Dla przykładu, w opracowaniu Tadeusza Sinki (Sinko 1927: 114) oraz wydaniu sejmowym (Mayenowa, Wilczewska 1991: 381) znalazł się przypis objaśniający słowo sam jako 'tu', natomiast w opracowaniu Juliana Krzyżanowskiego (Krzyżanowski 1967: 266) nie zamieszczono podobnego objaśnienia, co sugeruje, iż wyraz ten mógł tu zostać odczytany przez badacza jako zaimek odmienny w znaczeniu 'samotnie, bez towarzystwa'. W zbliżony sposób zinterpretował SPJK leksem w zdaniu (5) - jako zaimek, który „wyróżnia kogoś lub coś w sposób mniej kategoryczny, nieistotny dla rzeczownej treści zdania”. Wydaje się jednak, iż bardziej uzasadnione jest odczytanie przysłówkowe w znaczeniu 'tu', za czym przemawia cecha formalna - jasna samogłoska tematyczna. Dodatkowo interpretację tę potwierdza analiza większego fragmentu utworu, niż ten zacytowany przez słownik. Uwarunkowania kontekstualne oraz stylistyczne wskazują, iż wyraz wkomponowuje się w zastosowaną tu anaforę, polegającą na wielokrotnym powtórzeniu zaimka $t u$, stanowiąc jej ostatni, nietypowy element „logiczny”, tj. tożsamy jedynie znaczeniowo, różniący się formalnie, brzmieniowo.

Osobny komentarz warto dodać do zdania (6). Pochodzi ono z rękopisu, a więc z tekstu, w którym z założenia nie oznaczano barwy samogłosek. I tak jest w istocie: w liście do Stanisława Fogelwedera (1571) Kochanowski nie wyróżniał znakiem diakrytycznym $a$ jasnego. W tym jednak wypadku wyjątkowo uwidocznił barwę samogłoski, by rozwiać ewentualne wątpliwości odbiorcy. Za trafnością takiej opinii przemawiają odpowiednie fakty pozajęzykowe; w swoim traktacie na temat ortografii sam autor poucza, iż można

4 W zdaniu tym dodatkowym potwierdzeniem właściwego odczytania wyrazu jest możliwość odwołania się do odpowiedniego miejsca tekstu łacińskiego Jana Januszowskiego, analogicznego do Statutów Stanisława Sarnickiego: „quod nullus Zupparius debet solus sol vendere" (JanStat 164). 
zaniechać oznaczania barwy samogłoski $a$, o ile nie ma ona znaczenia dla warstwy semantycznej wyrazu (zob. JanNKarKoch D4v-E). W innym miejscu listu autor nie zapisał nad $a$ znaku diakrytycznego, co powoduje oczywiste wątpliwości interpretacyjne. Tu jednak znajomość treści większej części listu przemawia raczej za przysłówkowym odczytaniem zapisu, jak w SPJK:

(9) Wfzakże iefcże tego niedrukuię, będzie cżasu iefcze dofyć poprawić, si videbitur Tak my sam na wsi: Kiedi iuż zasieiemi, komin wkolo obsiędziemy, a ladaco i mowiemy i pifzemy (KochList $n l b .3$ )

Na podobnej zasadzie wyróżnikiem dwu odrębnych leksemów będzie oznaczenie barwy samogłoski tematycznej w przedstawionych poniżej dwu grupach przykładów: (10)-(12) oraz (13)-(14):

(10) MIkofz kotá przećiagnat/Ian fię rzezat w kofzu (KochFr 94)

(11) Aftragalus, [...] Kóty/ dźiecinna grá. [...] Aftragalifo, Graece, talis ludo, Kóty gram. (Mącz 18b)

(12) iáko to więc w tych widamy ktorzy ty koty igrawáią/ iż niepewni bywáią zdrowia fwego/ y długiego żywotá fwoiego. (RejZwierc 157v)

We wszystkich powyższych zdaniach mowa jest o grze, w której używa się kota. Rzeczownik kot z jasną samogłoską $o$ wystąpił w znaczeniu 'zwierzę domowe', a gra polegała na przeciąganiu przez rzekę lub kałużę sznura, do którego przywiązano kota. W zdaniu (11) użyty dwukrotnie wyraz z pochyloną samogłoską tematyczną ma inne znaczenie: 'kostka do gry'. W słowniku Knapiusza i u Lindego odnotowano ten sam apelatyw zapisany jako kut. Cytat (12) pochodzi z tekstu niekreskującego o pochylonego, zatem o znaczeniu rzeczownika kot orzekamy wyłącznie na podstawie kontekstu oraz świadomości istnienia w XVI wieku wyrazu różniącego się wyłącznie barwą samogłoski od tego, który przetrwał do naszych czasów jako nazwa zwierzęcia.

(13) Abyście fię w żadnych fektach/ okrom iedney powfzechney wiáry/ zbáwienia dufznego nie Jpodźiewáli (ReszPrz 111)

(14) A iefli fie chca [kobiety] cżego náucżyćl niech domá Jwych mężow pytáia. Bo żádna rzecż ieft niewieśćie w kośćiele mowić. (Leop 1.Cor 14/35) 
Również i w tych przykładach barwa tematycznej samogłoski jest cechą dystynktywną. Forma żådny oznacza bowiem 'ani jeden', żadny natomiast 'brzydki, nieodpowiedni'. Dodatkowym potwierdzeniem adekwatnego zrozumienia tekstu biblijnego jest odwołanie się do łacińskiego pierwowzoru: Turpe est enim mulieri loqui in ecclesia (Vulg 1.Cor 14/35). W polszczyźnie współczesnej drugi przymiotnik jest już całkowicie niezrozumiały, w XVI wieku funkcjonował obok innych wyrazów z tej rodziny, np. przysłówka żadnie ‘źle, nieodpowiednio':

(15) Ten ćy pirwey rad poczyna/ ktory żádnie y źle fpiewa. (March A3)

(16) Bo też zádnye y nieprzyftoynieby to było wyftáć s fzkoły nic fie nye náucżywffy (GliczKsiąż N2v)

Jak widać, umiejętność dostrzeżenia pewnych cech językowych oraz ich graficznego odzwierciedlenia jest niezwykle istotna dla należytego odczytania tekstu dawnego. Jednak można pójść dalej i zadać kolejne pytanie: czy sama doskonała i drobiazgowa wiedza językoznawcza okaże się w pełni wystarczająca, by móc stwierdzić, że należycie się dany utwór odebrało, zrekonstruowało w swojej świadomości?

Wiedza pozajęzykowa, jak np. świadomość praktyk wydawniczych dawnych drukarni może w znacznym stopniu ułatwić analizę konkretnych utworów literackich. Dla przykładu, wracając do wspomnianych już kwestii rekonstrukcji leksemów i ich znaczeń na podstawie analizy barwy samogłosek: pracę znacznie usprawni świadomość, że - choć w większości XVI-wiecznych oficyn drukarskich $a$ jasne oznaczano kreską - w kilku drukach stosowano odwrotną zasadę, zapisując $a$ pochylone z akutem, jak np. w wydanych w 1551 roku w Królewcu przez Aleksandra Aujezdeckiego tekstach Murzynowskiego - Historii żałosnej, Ortografii polskiej oraz Nowym Testamencie i Кирси Reja (1549), czy słowniku Calepinusa (Lugdunum, b.dr., 1588) - tu jako a z ogonkiem. Jeszcze lepiej, gdy dodatkowo badacz będzie miał na uwadze także inną cechę dwu ostatnich druków, mianowicie to, że barwę $a$ oznaczano w nich niekonsekwentnie, zatem zdarzało się, że nie zawsze zastosowano znak diakrytyczny dla å tam, gdzie być powinien. Na podobnej zasadzie wykorzystać można wiedzę, iż w słowniku Mączyńskiego (Królewiec: J. Daubmann, 1564), choć oznaczano barwę wszystkich samogłosek, e pochylone w końcówkach gramatycznych kreskowane było nie- 
konsekwentnie, a w późniejszym słowniku Knapskiego (Kraków: F. Cezary, 1643-1644, wyd. II) - stosowano dla $e$ odwrotną, od powszechnie przyjętej, zasadę oznaczania barwy tej samogłoski, zresztą również nie do końca konsekwentnie. W dodatku nawet w tekstach bardzo poprawnych - jeśli chodzi o zasady stosowania znaków diakrytycznych dla rozróżniania barwy samogłosek - należy zawsze mieć na uwadze, że owa konsekwencja zwykle dotyczyła wyłącznie tych części tekstu, które zapisane były szwabachą. W partiach drukowanych kursywą lub antykwą albo brak jakichkolwiek oznaczeń barwy samogłosek (co było również cechą majuskuły), albo są one bardzo niekonsekwentnie przeprowadzone. Oczywiście każdy językoznawca diachronista pewne rzeczy wychwyci od razu, jak np. odwrotne kreskowanie przy samogłosce $a$, zdziwi bowiem czytelnika powtarzalność zapisów w wyrazach mających zwykle dużą frekwencję, np.: pojawienie się $a$ z kreską w zaimku osobowym ja, czy bez kreski w a spójnikowym lub w końcówce -ać w przeważającej liczbie czasowników w bezokoliczniku. Wymagałoby to jednak dysponowania dłuższym fragmentem tekstu, co nie zawsze jest możliwe, w dodatku z jego reprezentatywną partią.

Kolejna rzecz, która jest wprost nieoceniona w ułatwieniu interpretacji tekstu dawnego, a niezwiązana ściśle z historycznojęzykową świadomością odbiorcy, to możliwość dotarcia do pierwowzoru, o ile mamy do czynienia z tekstem polskim będącym przekładem, tak jak już wskazałam na kilku wcześniejszych przykładach. Niekiedy bowiem zupełnie nie sposób należycie odczytać jakiś fragment bez znajomości tekstu oryginalnego. Ilustracją niech będą dwa przykłady z mało znanego XVI-wiecznego podręcznika do nauki języka łacińskiego dla dzieci i młodzieży, opartego na wyimkach z komedii Terencjusza (tzw. Rozmówki, 1545).

Polskie zdania, wraz z wyróżnionymi rzeczownikami:

(17) Adeo me ignauum putas. Ták że mie zá iebaká mafz. Adeo in humanum [!] putas. Ták że mie zá nieludzkiego mafz. Adeo ferum putas. Ták mie za nielutofćiwego mafz. (TerentMatKęt A8)

(18) Lenoni eripuit meretricem. Wydárt fzermierke Lenonowi. (TerentMatKęt I3v),

tylko z pozoru mogą wydawać się odbiorcy zrozumiałe, bowiem dopiero odniesienie do tekstu oryginalnego wskaże odpowiednią drogę interpretacyj- 
ną. Bez znajomości tekstu łacińskiego rozumowanie czytelnika będzie biegło raczej w oczywistym kierunku: w pierwszym zdaniu rzeczownik jebak odczytany zostanie jako bezdyskusyjne obscenum, w drugim - intuicyjnie szermierke odniesie się do rzeczownika męskiego szermierz 'człowiek znający sztukę władania białą bronią. Dla rzeczownika jebak ${ }^{5}$ SPXVI (odnotowano tu wyłącznie omawianą egzemplifikację tekstową) podaje definicję 'człowiek gnuśny, leniwy', która tu okazuje się jednak nieadekwatna. Łac. ignavus ma kilka znaczeń, w tym wyżej wymienione oraz 'człowiek podły, nikczemny, niegodziwy', co można uznać za właściwe temu konkretnemu użyciu. Za ową interpretacją przemawiać tu będą zatem jeszcze inne względy, mianowicie znajomość komedii Terencjusza (fragment pochodzi z Aktu I, sc. 5 Andrii), a nie bazowanie wyłącznie na fragmentach zapisanych w utworze Mateusza z Kęt ${ }^{6}$. Poza tym istotny może okazać się fakt, iż w kolejnym wydaniu Rozmówek (1586) wyraz zastąpiono rzeczownikiem gnoj, który w XVI-wiecznych nominacjach człowieka powinno się rozpatrywać jako wieloznaczny. W zdaniu (18) wszelkie watpliwości rozwieje oczywiście strona łacińska, która wyraźnie wskazuje, iż szermierka tłumacz nazwał heterę, nierządnicę, a i w tym wypadku w kolejnym wydaniu nastąpiła korekta: zapisano w tym miejscu rzeczownik fryjerka. W omawianym zdaniu wystapiła jednak kolejna zawiłość. Na pierwszy rzut oka wydaje się, iż zapisano tu nazwę proprialną Lenon. W rzeczywistości jednak tłumacz dokonał niecodziennego zabiegu, sugerując niejako, że mamy tu do czynienia z nazwą własną. We wszystkich użyciach wyrazu w swoim podręczniku Mateusz zapisał go - zarówno po stronie polskiej, jak i łacińskiej - wielką literą, a ponadto nigdzie nie przetłumaczył łac. leno 'stręczyciel', wplatając to słowo w tekście polskim w oryginalnym brzmieniu. U podstaw takiej transpozycji, podobnie zresztą jak to miało miejsce przy rzeczowniku szermierka, leżały zapewne

5 SW pod hasłem jebać (gwarowe) notuje - poza 'spółkować', również dwa inne: 'besztać', 'bić', zaś Aleksander Brückner (1903: 314) łączy użyty w Rozmówkach rzeczownik z łużyckim czasownikiem 'oszukiwać'.

${ }^{6}$ Tu cytat (17) poszerzyłam o dwie kolejne frazy łacińsko-polskie, ponieważ w Terencjuszowym oryginale stanowią całostkę w wypowiedzi bohatera dramatu, stanowią też dobrą ilustrację dla wywodów.

7 Por. dwa inne wystąpienia rzeczownika w zdaniach: Seruiebat Lenoni impurifsimo.

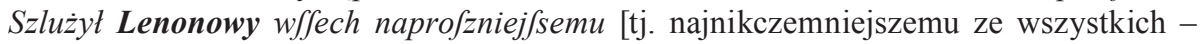
ALK]. (TerentMatKęt M2); Ad Lenonem hic ire pergam. Poydę z tad do Lenoná. (TerentMatKęt O3v). 
względy obyczajowe: książka miała służyć pomocą przy nauczaniu szkolnym dzieci i młodzieży, a autor prawdopodobnie nie chciał siać wśród nich zgorszenia, w związku z tym nie wspominał o budzących społeczną dezaprobatę zawodach ${ }^{8}$.

Być może możliwość odwołania się do odpowiedniego miejsca łacińskiego dramatu Castus Ioseph Szymona Szymonowica stanowiłaby pewną wskazówkę, jak należy odczytać wyróżniony fragment wspominanego już tłumaczenia autorstwa Stanisława Gosławskiego (1597):

(19) Gdźiéż teraz/ nieftéty/ Rozum twóy? á nie glupié té twoie nátręty/ Którémi teraz robifz/ gdy źrzódłá nowégo Iákiéyśi wody prágniefz? (GosłCast 25)

Interesujący nas fragment jest tu jednak niestety tylko dodatkiem tłumacza, jak wynika z opracowania stosunku tekstu tłumaczenia do oryginału dokonanego przez Jerzego Axera. W opracowaniu Konrada Górskiego i Teresy Kaufmanowej (1973: 112) zdanie zapisano w transkrypcji:

(19.a) Á nie glupié té twoje nátręty, Któré mi teraz robisz,

zatem uznano, że w starodruku - bardzo zresztą starannie wydanym - błędnie nie zapisano spacji przed zaimkiem osobowym, a w zdaniu wystapiła struktura składniowa: robić komu natręty. Tę samą linię interpretacyjną zachował SPXVI, skoro pod hasłem natręt 'natarczywość' ten właśnie cytat umieścił w zwrocie natręty [komu] robić 'naprzykrzać się'. Jednakże w kolejnym tomie SPXVI przychylono się już do innego odczytania owego fragmentu: w haśle robić w znaczeniu 'posługiwać się, stosować, używać, wykorzystywać' znalazł się on w podgrupie syntaktycznej robić czym. Za taką interpretacją przemawiały tu uwarunkowania składniowe - wśród XVI-wiecznych użyć czasownika brakuje choćby jednego wystąpienia struktury robić co komu, w odróżnieniu od dość licznie reprezentowanej robić czym. Samo odczytanie tekstu wydaje się słuszne, choć kwalifikacja znaczeniowa może budzić zastrzeżenia. Wydaje się, że struktura robić natrętami powinna znaleźć

${ }^{8}$ Więcej na temat korektur w przekładzie Mateusza z Kęt, mających swe źródło w XVI-wiecznej obyczajowości, tu wynikających jednak przede wszystkim z dydaktycznego przeznaczenia książki zob. Luto-Kamińska (2013). 
się w grupie podobnych użyć w innym znaczeniu ('wykonywać jakąś czynność, zajmować się czymś; postępować jakoś'), w których użyty narzędnik ogólnie wskazuje na pewien określony sposób postępowania, np.:

(20) Niech Kśięża mówiq cáty dźién paćierzel Ia iuż przeftawam ná fwéy proftéy wierze. Iż rad żártámi/gdy mam fczęśćié/ robię (PudłFr 5)

(21) wftyd mię niefzczerościa Robić (CiekPotr 60)

Opierając się na przykładowo wybranych egzemplifikacjach, można utwierdzić się w przekonaniu, że przy pracy z tekstem dawnym, przy jego interpretacji, czy szczegółowym opisie filologicznym wiedza z zakresu językoznawstwa diachronicznego jest nieodzowna. Jednak i ta - jak się okazuje - w wielu wypadkach bywa niekiedy niewystarczająca, konieczne są bowiem odwołania do wiedzy pozajęzykowej, np. z zakresu szeroko pojętej historii języka lub w ogóle historii. Językoznawca występujący w roli czytelnika winien zwrócić uwagę na takie szczegóły, które komuś innemu mogą umknąć lub wydać się nieistotne, wnioskować na podstawie przesłanek lingwistycznych, szukać podpowiedzi w drobiazgowych analizach języka tekstu na różnych poziomach, włączając tu również analizę graficzną, stylistyczną, niekiedy translatologiczną. I choć wiedza historycznojęzykowa jest w tym wypadku kwestią bezspornie podstawowa, nie powinien przy tym gardzić pozyskiwaniem informacji z wszelkich innych możliwych źródeł, by odczytanie dzieła literatury staropolskiej było jak najpełniejsze.

\section{Źródła}

BielKron - M. Bielski, 1564, Kronika, to jest historyja świata..., Kraków: M. Siebeneicher.

CiekPotr - P. Ciekliński, 1597, Potrójny z Plauta, Zamość: Druk. Akademii, M. Łęski.

GliczKsiąż - E. Gliczner, 1558, Ksiażki o wychowaniu dzieci..., Kraków: M. Siebeneicher.

GosłCast - S. Gosławski, 1597, Castus Ioseph..., Kraków: Druk. Łazarzowa, J. Januszowski.

JanNKarKoch - J. Januszowski, 1594, Nowy karakter polski [...] i Ortografia polska Jana Kochanowskiego, Jego M. P. Łukasza Górnickiego, [...] Jana Januszowskiego, Kraków: Druk. Łazarzowa, J. Januszowski. 
JanStat - J. Januszowski, 1600, Statuta prawa i konstytucyje tacińskie i polskie, z Statutów Laskiego i Herborta i z Konstytucyj Koronnych zebrane..., Kraków: Druk. Łazarzowa, J. Januszowski.

KochCz - J. Kochanowski, 1589, O Czechu i Lechu historyja naganiona, Kraków: Druk. Łazarzowa, J. Januszowski.

KochFr - J. Kochanowski, 1584, Fraszki, Kraków: Druk. Łazarzowa, J. Januszowski. KochList - J. Kochanowski, 1571, List do Fogelwedera (rkp.), Czarnolas.

KochPieś - J. Kochanowski, 1586, Pieśni..., Kraków: Druk. Łazarzowa, J. Januszowski.

KochTarn - J. Kochanowski, 1586, O śmierci Jana Tarnowskiego..., Kraków: Druk. Łazarzowa, J. Januszowski.

Leop - J. Leopolita, 1561, Biblija, to jest księgi Starego i Nowego Zakonu..., Kraków: Dziedzice Marka Szarffenberga.

March - Jan z Koszyczek, 1521, Rozmowy, które miat król Salomon madry z Marchottem grubym a sprosnym..., Kraków: H. Wietor.

Mącz - J. Mączyński, 1564, Lexicon Latino-Polonicum, Królewiec: J. Daubmann.

PudłFr - M. Pudłowski, 1586, Fraszek księga pierwsza..., Kraków: Druk. Łazarzowa, J. Januszowski.

RejZwierc - M. Rej, 1568, Źwierciadło albo kstalt, w którym każdy stan snadnie się może swym sprawam jako we źwierciadle przypatrzyć..., Kraków: M. Wirzbięta.

RejZwierz - M. Rej, 1562, Źwierzyniec, w którym rozmaitych stanów ludzi, źwirząt i ptaków kstalty, przypadki i obyczaje sq właśnie wypisane..., [Kraków: M. Wirzbięta].

ReszPrz - S. Reszka, 1585, Przestroga pastyrska..., Poznań: J. Wolrab.

SarnStat - S. Sarnicki, 1594, Statuta i metryka przywilejów koronnych..., Kraków: Druk. Łazarzowa, J. Januszowski.

TerentMatKęt - Mateusz z Kęt, 1545, Ex P. Terentii comediis Latinissimae colloquiorum formulae..., Kraków: M. Szarffenberg.

\section{Bibliografia}

BrüCKner A., 1903, Przyczynki do słownictwa polskiego, Kraków: Nakładem Akademii Umiejętności, Druk. Uniwersytetu Jagiellońskiego.

Chmielowski P., 1898, Nasza literatura dramatyczna, t. 1, Petersburg: Nakładem Księgarni K. Grendyszyńskiego.

Górski K., Kaufmanowa T. (opr.), 1973, S. Gosławski, Castus Ioseph, Wrocław-Warszawa-Kraków-Gdańsk: Zakład Narodowy im. Ossolińskich, Wydawnictwo Polskiej Akademii Nauk. 
Hahn W., 1906, Literatura dramatyczna w Polsce XVI wieku, w: Archiwum Naukowe. Wydawnictwo Towarzystwa dla Popierania Nauki Polskiej, Dział I, T. III, zesz. 3, Lwów: Nakładem Towarzystwa dla Popierania Nauki Polskiej, Drukarnia Uniwersytetu Jagiellońskiego.

KrzyŻAnowski J. (opr.), 1967, Jan Kochanowski, Dzieła polskie, t. 1, Warszawa: Państwowy Instytut Wydawniczy [wyd. 5].

Luto-Kamińska A., 2013, Między dosłownościq a obyczajowościa (o wpływie norm kulturowo-obyczajowych na oddawanie w przekładzie realiów stanowiacych temat tabu w kulturze tłumacza), w: Prace Komisji Językoznawczej Bydgoskiego Towarzystwa Naukowego, t. XXIII: Język - wielokulturowość - tożsamość, Bydgoszcz [w druku].

Mayenowa M. R., WilczewsKa K. (opr.), 1991, J. Kochanowski, Dzieła wszystkie. Wydanie sejmowe, t. 4: Pieśni, Wrocław-Warszawa-Kraków: Zakład Narodowy im. Ossolińskich, Wydawnictwo PAN.

NAdOLSKI B., 1952, Dokoła prac przekładowych w XVI wieku, Wrocław: Wrocławska Drukarnia Naukowa.

Sinko T. (opr.), 1927, J. Kochanowski, Pieśni i wybór innych wierszy, Kraków: Nakładem Krakowskiej Spółki Wydawniczej, druk. W.L. Anczyca i sp.

SPJK: KucAŁa M. (red.), 2008, Słownik polszczyzny Jana Kochanowskiego, t. 4, Kraków: Wydawnictwo Instytutu Języka Polskiego PAN.

SPXVI - Mayenowa M. R., PepŁowski F. (red.), 1975 (t. 9), 1985 (t. 16), 2011 (t. 35), Słownik polszczyzny XVI wieku, Wrocław-Warszawa-Kraków-Gdańsk-Łódź: Zakład Narodowy im. Ossolińskich, Wydawnictwo IBL PAN (oraz materiały z kartoteki pracowni tegoż słownika w Toruniu).

SW - KarŁowicz J., KryŃski A., Niedźwiedzki W., 1952, Słownik języka polskiego, t. 2. Warszawa: Nakładem prenumeratorów i Kasy im. Mianowskiego, Drukarnia „Gazety Handlowej”.

Zawiliński R. (opr.), 1889, Szymona Szymonowicza Castus Ioseph przekładania Stanisława Gosławskiego 1597, w: Biblijoteka Pisarzów Polskich, Kraków: Drukarnia „Czasu” Fr. Kluczyckiego i sp.

\section{On reading and decoding the works of early modern Polish literature. Does a linguist read differently?}

( s u m m a r y)

The paper discusses how the knowledge of historical linguistics can contribute to appropriate understanding and interpreting of old texts. Selected examples serve to demonstrate that a detailed linguistic analysis can help to both appropriately decode particular words with their semantic and grammatical features, and to understand 
the text itself. However, a comprehensive linguistic analysis of an old text is effective only when the researcher examines the original text or its duly prepared transliteration as it enables them to draw certain conclusions, for example on the basis of vowel articulation.

The paper also emphasises the necessity to refer to extralingustic knowledge of broadly understood history of language or to history in general. Thus, it is useful to be acquainted with old manuscript and editing techniques applied in particular printing houses, and to be able to conduct a comparative analysis of original texts and their translation or a lexicographic analysis, and to refer to general cultural background. 